\title{
Contemporary Perspectives on Fiscal Decentralisation and New Local Government in South Africa
}

\author{
Nyawo Gumede \\ Sol Plaatje University, School of Economics and Management Science. South Africa \\ nyawo.gumede@spu.ac.za \\ John Byamukama \\ Sol Plaatje University, School of Economics and Management Science. South Africa \\ john.bymukama@spu.ac.za \\ Edward Dakora \\ (Corresponding author) \\ Sol Plaatje University, School of Economics and Management Science. South Africa \\ edward.dakora@spu.ac.za \\ DOI//http://dx.doi.org/10.4314/gjds.v16i2.3
}

\begin{abstract}
There are shared thoughts among scholars that fiscal decentralisation is a solution to the problems of poor public services in the local government. Fiscal decentralisation is the dispersal of financial responsibility to lower levels of government or other spheres of government. This study highlights various discourses on local self-government, especially fiscal decentralisation processes, local revenues, and the New Local Government philosophy of local government reform in South Africa. This research interrogates the importance of fiscal decentralisation as a tool to facilitate greater effectiveness and efficiency in local government. A qualitative research approach was used to obtain information. Through the review of the literature and selected official government reports, the study found that development in local government can be achieved through the effective decentralisation of responsibilities, fiscal policy management, fiscal decision-making authority and sufficient resources, including revenue collection authority to local authoritiesFiscal decentralisation requires a concerted effort in capacity-building and institutional fiscal reform and should, therefore, be associated with the strengthening of local authorities. Decentralisation can occur at the level of fiscal expenditures and revenues creation or sourcing. This paper
\end{abstract}


emphasises the importance of fiscal decentralization and the New Local Government philosophy of local government reform.

Keywords: Fiscal Decentralisation, Local Revenues, New Local Government, Finances

\section{INTRODUCTION}

In most post-colonial states, fiscal decentralization has been a subject of acute administrative debates. Fiscal decentralisation is a critical issue in municipal public finance. Fiscal decentralization is the dispersal of financial responsibility to lower levels of government or other spheres of government. Local or regional governments can perform their decentralised duties efficiently, effectively, productively and competitively if they have sufficient amounts of revenues that are raised locally or adequately transferred from the national government (Elhiraika, 2006). Sufficient authority to make decisions with regard to expenditures is essential. Fiscal decentralization can assume various forms including, self-financing or cost recovery through user charges, co-financing or co-production arrangement through which the users partake in providing services and infrastructure through monetary or labour contributions, and expansion of local revenues through property sales taxes.

In South Africa, local governments or municipalities possess the legal authority to impose taxes, but the tax base is so weak, and the dependency on national sphere subsidies is so ingrained that no attempt is made to exercise that authority. Fiscal decentralisation can lead to economic growth and development if it is applied properly and conceptualised as a development strategy to facilitate local participation at the local sphere of government. Striking a balance between fiscal decentralisation and economic performance is challenging in most African countries. Fiscal decentralisation entails the financial aspects of devolution. In Europe or America, they use the term fiscal federalism depending on their centrallocal financial relations (Smith, 1985). There are significant issues which fiscal decentralization deals with, including, the collection of revenue and allocation of responsibilities to municipal departments to think strategically on how to improve and sustain the income and how it is used to improve service delivery and development. It is critical to note that fiscal decentralization implies the percentage of total government expenditure used by local governments, considering the size and character of transfers, or the level of tax autonomy of local governments or both.

Most colonial regimes did not adequately prepare their colonies for independence. Thus, the political and administrative architecture inherited at independence was 
wholly fraught with a plethora of structural administrative and structural-financial debilities, which took years, for the post-colonial states to deal with or redress. The conceptualisation of fiscal decentralisation was, however, biased towards political transformation than the administrative. Fiscal decentralisation involves the dispersal of financial responsibility to local government. For this to happen successfully, the local government must have sufficient revenue base either collected or levied locally or obtained from the national sphere of government. This would result in granting local government adequate decision-making powers to determine expenditure. It is significant to understand that in discussing decentralisation a distinction between devolution and deconcentration must be made.

Devolution refers to the distribution or redistribution of authority to make decisions and to take action by local governments independently of national administrative oversight. National governments might retain overall legal control (equal protection under the laws, voting eligibility, allocating authority to raise revenue, ensuring general law and order, and regulating fraud and corruption and authority to alter local government powers) (Cohen \& Paterson, 1996). Furthermore, through devolution, the local government has substantial authority to hire, fire, tax, contract, invest, plan, set priorities, and deliver municipal services. Deconcentration, in contrast, occurs when local entities act largely as the agents of central governments, manage personnel and expend resources allocated to them by central authorities. Deconcentration involves the distribution of resources to localities on the sufferance of those central authorities (Cohen \& Peterson, 1996).

Decentralisation refers to the transfer of authority and responsibility for public functions from the national government to local municipal government. The typologies of decentralisations are political, administrative, fiscal, and market decentralisation (Dubois \& Fattore, 2004). In the Philippines, the government passed the Local Government Code to effect decentralisation in the country. The Code is used to decentralise governance in the Philippines by devolving the power and functions of local government units and the strengthening of the people's participation in local governance, and it comprises four distinct approaches, which include:

(1) Devolution (which implies the conferring of power and authority by the central government to the local municipal units).

(2) Deconcentration (the increase and further delegation of functions, responsibility, and authority by the national office to appropriate provinces and field offices).

(3) Privatisation (the outsourcing of government projects to private businesses). 
(4) Participation (the involvement of non-governmental organisations in active decision-making processes) (Teenhankee, 2003).

The United Nations (UN) has adopted some guidelines on decentralisation. It stipulates that effective decentralization and local autonomy require appropriate financial autonomy. The UN also recommended that where national or provincial governments delegate powers to local municipalities, local authorities should be guaranteed the delegated powers to them and the resources necessary to exercise these powers as well as the discretion in adopting the execution of these tasks to local conditions and priorities. United Nations also propounded that local authorities should have access to a wide variety of resources to carry out tasks and responsibilities (UN, 2005). During the apartheid epoch, white local authorities were financially supported by the national government more than black local authorities. Fiscal decentralisation was very difficult owing to the policy of separate development or apartheid.

The existence of homelands, self-governing territories and four provinces under racially - motivated, separate administrative and political units, made it impossible to have a democratic fiscal decentralization policy in South Africa. Fiscal decentralisation involves the fiscal utilisation responsibility, local income sources, and the financial decision-making powers, devolved to local municipalities, to determine their local expenditures and revenues. The Auditor-General in South Africa released a general report with audit outcomes of local government for the 2017-2018 financial year, which highlighted the fiscal management failures and discipline of 257 municipalities and 21 municipal entities in South Africa. Only 8\% of the municipalities managed to obtain clean audits and irregular expenditure at the municipal level was to the tune of R21, 243 billion (Auditor-General, 2019). This is a challenge that fiscal decentralisation has in South Africa. The Auditor-General depicted the lack of administrative leadership and poor financial management in most municipalities in South Africa.

\section{Background}

Decentralisation has been implemented in many developing countries in the postcolonial epoch. The meaning of decentralisation varies from one state to the other; thus consequently, countries produce different programmes, conceptual frameworks, and policies on decentralisation. Decentralisation means the transfer of powers from the national government to the local government in a politicaladministrative and territorial hierarchy (Agrawal \& Ribot, 1999). 
African political decentralisation emphasises the transfer of authority to local institutions and persons, such as elected local governments. It may refer to a broad range of transfers of the locus of decision making from national governments to provincial, municipal or local government, thus, allowing local participation of people and local authorities. In simple terms, decentralisation implies the transfer of power from the central to provincial level or delivering management roles to other local government. Most African countries have implemented decentralisation reform. Given the preceding, it can be deduced that albeit assuming various specific forms decentralisation reform generally disperses power that previously had been concentrated in central governments, in fact, what in some countries is referred to as a national government. This means that in Africa, under decentralisation, government power is entrusted to municipal institutions that are very close to the citizens at the grassroots level.

If Practised properly and implemented appropriately, decentralisation reform in Africa, has a uniquely vast opportunity of ameliorating the quality of government at the local level in African countries like South Africa and the rest of the developing and underdeveloped world. Decentralised governance is increasingly being favoured by many African countries as the most suitable method of government through which poverty reduction initiatives can be deliberated, planned, implemented, supervised, and assessed (Kauzya, 2007). Kauzya further argues that the process of decentralisation will facilitate greater participation of communities in problem analysis, project identification planning, implementation as well as oversight which in turn will increase ownership and the sustainability of such initiatives. In Uganda decentralisation was born from the logic of searching for support for the Guerrilla War and introducing participatory democracy. In South Africa, decentralisation refers to giving local people the power to select their political leaders at the local government level. This transfer of power and authority is usually done by the national government to their local municipalities. Decentralisation also means the spreading of power and authority for decision-making purposes from the national government to the local sphere of government (Kauzya, 2007).

This paper adopts the following World Bank definition of fiscal decentralisation: that, fiscal decentralisation involves the fact that previously concentrated powers to tax and generate revenues are spread to lower levels of government, for instance, municipalities are imparted the powers to raise and retain financial resources to fulfill their responsibilities (World Bank,200o). It is critical to note that most African countries have witnessed personalised, fused, and extremely centralised governance system and practices, during the pre-colonial era, the colonial and the post-colonial period. In the pre-colonial period, traditional Kings, 
Paramount Chiefs, local Chiefs, and Indunas had absolute powers and authority in the governance of their tribal kingdoms and empires. The colonial masters of Africa had highly centralised systems to maintain control in the colonies and for security reasons. At independence, most African countries, decided to reform their administrative systems, thus adopting decentralisation.

In 1994, a novel democratic government replaced the autocratic apartheid colonial government in South Africa. The demise of the illegitimate apartheid government opened ways for reforms to take place. Political reforms that were enacted saw the establishment of a unitary state which was, however, decentralised into three spheres of government, namely: national, provincial, and local government in what is called a system of cooperative governance. In the past, South Africa had four provinces, homelands, and self-governing territories, which were all replaced by the enactment of nine provinces. Under apartheid, a local government comprised of over 1200 racially-based local authorities. In 1995, 843 transitional municipalities were created. In 2000, the number was reduced to 284 municipalities (47 District, 6 Metros, 231 Local Municipalities) (G.T.Z., 2006).

The principle of decentralisation is enshrined in the Constitution of the Republic of South Africa of 1996. Each of the spheres of government has its powers and responsibilities. The principle of co-operative governance is key to the operation of all the spheres of government in South Africa. Under apartheid, fiscal centralisation was very common just as in many colonies in Africa, but the trend has dramatically taken a different direction. In most African countries, at independence, the infrastructure for implementing fiscal decentralisation was either poor or not there because the colonial administrations were not interested in local economic development but saw Africa as a source of raw materials and markets. Local economic development was not a priority to the colonialists. The traditional system in some parts of the world, particularly in Asia, has been centralised for centuries. Local governments were introduced in many developing states through colonialism and development assistance, often taking a form that neither met their intended purposes nor gained acceptance from the local people (Smoke, 2001).

African leaders inherited an institutional framework that was not consistent with their culture and needs. They used local government for administrative and control purposes rather than promote self-determination, democratisation, and economic development (Smoke, 2001). Central planning discouraged any form of decentralisation in developing countries, especially those that were aligned to the Socialist/Communist Bloc, during their liberation struggles. These countries sought guidance from the principles pursued in industrial countries where market preserving systems of public decision making have evolved over a long period. 
In Africa, both former French and English colonies inherited a highly centralised system of governance geared towards command and control with little regards of citizen's choices (Shah, 2002). Fiscal decentralisation has been propelled by many factors. The culture of governance changed in the 12th century, from a bureaucratic to a participatory mode of operation from a command and control to accountability for results.

The culture of governance is also slowly changing from a bureaucratic to a participatory model; from command and control to accountability for results; from being internally dependent on being competitive and innovative; from being closed and ineffective to being transparent and effective; and from that of intolerance for risk a liberal one (Shah, 2002). Localization has been pursed through varying combinations of political, administrative, and fiscal decentralisation initiatives (Shah, 2002). Fiscal decentralization is completely different from fiscal centralisation. In the first place, the two are practiced for absolutely different reasons. Fiscal decentralisation is seen as occurring mainly on the revenues side, concerning tax assignment and transfer of revenues between levels of government.

In this case, fiscal decentralisation directly changes, the authority of local government officials when it expands their right to obtain additional tax revenues or when it legislates a formal municipal role in expenditure policy (USAID, 2009). It should be noted that some local municipalities fail to improve their revenues due to failures in debt collection methods and mechanisms. Recently, the AuditorGeneral in South Africa found out that inability to collect debt efficiently and effectively was rife amongst municipalities. The Auditor-General, in this light, argued that municipalities in this type of problem ultimately fail to balance their books (Auditor-General, 2019). With particular regard to revenue, the most common types of fiscal decentralization include increasing the transparency and stability of transfers endowing sub-national governments with the power to collect their taxes and to set the rates of these taxes, and giving local governments the right to borrow with greater independence from the national government.

\section{Principles that Inform Revenues}

At the local government level, there are principles that inform local revenues. Local revenues are critical in the LED programmes of the municipality. The following principles inform local revenues at the local government sphere,

- Increasing revenue transfers and referring tax authority are both important types of fiscal decentralisation, but the latter has a more positive impact on accountability: paying more their taxes at the sub-national level may 
encourage taxpayers to hold local government officials accountable for the spending of these revenues.

- At the same time, the assignment for some tax bases to local government levels (for example, taxes with mobile bases and taxes structured for redistribution) can be inappropriate and potentially lead to great inefficiencies.

- The design of intergovernmental transfers should be based on some principles, including rule-based definitions of transfer fund pools, transparency and objective transfer allocation formulae, and incentives for the sub-national government to raise local revenues.

- Local government should be based on an assessment of their creditworthiness and the economic viability of specific development projects for which capital financing is being sought (USAID, 2009).

\section{Local Government Fiscal Sustainability}

The ability by the sub-national government to cover its expenditure or expenses from its local revenues, depleting its parasitic dependence on borrowing and national government fiscal transfers, is called sub-national fiscal sustainability. In the pre-1994 South Africa, Black local Authorities (B.L.A) were not financially sustainable owing to a plethora of socio-economic factors ranging from the non-payment culture from black communities (non-payment, was used by black people in South Africa as a sign of resistance to colonial apartheid rule) to weak revenue resources base. Financially, the black people leaving in black communities which were under black local authorities were weak, also owing to the economic underdevelopment that took place in the areas in the pre-1994 epoch.

At the local government level, the concept of fiscal sustainability has to be viewed differently because the ability of municipalities to manage their revenues base and more than often also their expenditure are largely restricted by higher national levels of government. Provincial governments or regional government act are watchdogs of local municipalities. Their expenditures are monitored by provincial officials or regional government officials. Provincial or regional government officials are influential in the establishment of municipal demarcations in terms of boundaries although in some countries the municipal demarcation board deals with the municipal boundaries and report to the provincial government as the higher governmental order and it is accepted as legal and constitutional. The provincial government determines the operations of municipalities with regards to the local revenues they can raise and their sources. Provinces set detailed rules on how to collect revenues for the local authorities. This type of control implies that 
municipalities operate under serious provincial control, and hence, there is no need for them to fail financially, but it is the opposite. With all the provincial or regional control, municipalities still fail to deliver local services effectively and efficiently.

There is a serious problem of fiscal discipline in many municipalities (Ribot, 2002). However, other municipalities perform well despite the problems they face. Such municipalities were able to obtain a clean financial audit for the 2017/18 financial year, and twelve of these municipalities are in the Western Cape province of South Africa. They include municipalities of Swellendam, Witzenberg, Bergrivier, Breede Valley, Cape Agulhas, Cederberg, Hessequa, Matzikama, and Overstrand (AuditorGeneral, 2019:2). There are two dimensions of local government fiscal sustainability namely the static dimension (the relation of the levels of revenues and expenditure) and the dynamic dimension (the relation of the growth rate of income and the expenditures). Thus, sustainability could, for example, be measured by looking at the buoyancies/elasticities between expenditure and economic growth and also income and growth, should the former be more buoyant /elastic than the latter, sustainability could become problematic over time (Ribot, 2002).

\section{Forms of Fiscal Decentralisation}

In most post-colonial states, dependency on the national government is financially overwhelming. This kind of financial dependence is constitutionalised. There is an increased tendency by most post-colonial or post-apartheid government to centralise authority and power at the central level or national sphere of government, usually for political reasons than administrative. This is the case for countries that are led by former liberation movements that are dictatorial or that possess such characteristics. De facto one-party dominated countries like South Africa have substantive traces of the above, and, consequently, financial decentralisation is difficult. Fiscal decentralisation assumes various forms including, self-financing, co-financing, broader development of municipal revenues, intergovernmental fiscal transfers, and authorisation of local governmental borrowing (Sharma, 2005:44).

It is important to understand that provinces have limited financial resources and revenues of their own and that they mainly have an equitable share in the national revenue. This follows from the traditional South African approach that the national revenue is indivisible - the country has a so-called single revenue system (De Villiers, 2008). Municipalities also depend on the allocation from the national government and are constantly monitored by their respective provinces or regional governments. 
Fiscal decentralisation has merits and demerits for local governments across the world. Fiscal decentralization increases effectiveness, efficiency, and productivity in services delivery at the local sphere of government. Fiscal decentralisation influences local economic development initiatives. However, the greatest challenges that South Africa faces at this lower spheres of government are extreme political interference with fiscal, administrative operations by the local political elites and systemic and institutional corruption by politically appointed managers. The classic argument in favour of decentralisation is that local governments are more efficient and responsive to the needs of the citizens as well as being held to a higher level of accountability than national government structures and in spatial terms local governments become a necessary conduit for setting up an efficient solution for equating benefits and costs for service delivery (Alfano, 2009).

Higher levels of heterogeneity generate demands for decentralisation or even secession, and many countries stopped this secede demand opting instead for a fiscal decentralisation scheme (Alesina \& Sporaore, 1997). Decentralisation is important because it puts local government nearer to the local people and, hence, it is easy to deal with their demands. Fiscal decentralisation has benefits of engendering efficiency and effectiveness in local fiscal decision making and greater local participation in resources allocation and distribution.

\section{The Motivation for Fiscal Decentralisation}

Fiscal decentralisation capacitates local municipalities to consider their varying environments, socio-cultural, socio-economic disparities when allocating services. Fiscal decentralisation enables municipalities to manage their natural resources and their socio-economic institutions to the benefit of the local people. Information on local needs and demands can be obtained by local municipalities less expensively (De Mello, 2006). Fiscal decentralisation propels greater accountability and transparency in the use of municipal public funds at the municipal level. Fiscal decentralisation helps in promoting local traditions and restructuring of the public sector. Fiscal decentralisation is very critical in promoting greater local fiscal autonomy and transparent fiscal governance, which naturally promotes local economic growth (LEG) and ultimately lead to poverty alleviation (De Mello, 2006).

Fiscal decentralisation is useful for the local government to take ownership and control of their fiscal resources. In South Africa, local government Integrated development plans (IDPs) permit effective and efficient local community participation in decisions over their financial priorities and local economic development. Fiscal decentralisation, enables local government authority, to re- 
distribute scarce resources in line with local development expectations. It enhances, the allocative efficiency and the redistributive effectiveness in local service delivery.

\section{Demerits of Fiscal Decentralisation}

The major disadvantage of fiscal decentralisation is that it creates a framework of expenditures, revenues and legal discretion within which provincial and municipalities or councils function, but fails to address matters of fiscal management and broader municipal accounting practices, dispersal of municipal authority, local supply chains management and compliance issues of which are utilised by local councils to manage their finances (Davey, 2003). One of the pitfalls of fiscal decentralisation is its inability to provide an adequate method to deal with the administration of intergovernmental fiscal relations in order to deal with the rising demands of local service delivery in municipalities, while maintaining financial discipline at provincial and at central government level. It should be noted that different municipalities are impacted by different levels of fiscal decentralization, and this consequently affects their fiscal discipline and fiscal accountability and responsibility (Sharma, 2005). The two limitations outlined are largely propelled by the critical shortage of qualified staff. Ruling political parties interfere with local administrations to get a firm grip on political power. This is the case with de jure one party-states that are rife in Africa (Robinson, 2004). The success and failure of fiscal decentralisation also depend on the socio-political history and economic expediencies of one country to the other.

\section{Challenges of Fiscal Decentralisation}

In Africa, fiscal decentralisation and decentralisation, in general, faces a plethora of challenges at the local government level. The World Bank Institute has identified manifold challenges of fiscal decentralisation. The Institute argues that greater fiscal autonomy may not result in improvements in service delivery at local government level (WBI, 2005). There are no common norms and standards for quality local government service delivery globally. This inhibits the municipal abilities to assess the impact of fiscal decentralisation on the poorest segments of the local communities. The other main challenge is the problem of lack of institutional and technical capacity to implement proper service plans which reflect the needs of the local people. Finally, most local municipalities fail to integrate local preferences in their IDPs. The other challenge is the systematic and systemic corruption which local municipalities experience. The levels of corruption or financial misconduct is very high in most municipalities to the extent that very few municipalities get clean audits from the Auditor-General. As far as fiscal decentralisation is concerned, attention should be directed towards political commitment and effective leadership 
about pro-poor, decentralised service delivery, mobilisation, institutionalised participation of all groups of society, the provision of adequate financial resources and the strengthening of technical and managerial capacity (WBI, 2005).

The other challenge of fiscal decentralisation is transparency at the local municipal level of government. Political interference by the dominant political parties in the financial process is rife, in most municipalities in South Africa. Underdevelopment is one of the critical challenges in formerly blacks-only settlements. Owing to the poor economic infrastructure in those areas, investors do not want to risk their investment in such areas. Thus, the potential for local revenue is affected. Most municipalities in South Africa depend wholly on provincial and national government financially and, as such, they fall into the category of CliMUs, (client municipalities).

Municipalities also depend on the Development Bank of Southern Africa (DBSA) for municipal infrastructure grants. They get the budget and spend it each financial year with no effort whatsoever to become independent from the upper tiers of government.

All Metros, District and local municipalities after 1994 are CliMUs. The argument put forward by the New Local Government philosophy of local government reform is that municipalities must be able to generate more revenue through municipal share ownership schemes in which the municipality purchase shares in the local businesses within its jurisdiction. This will help the municipality to stop being a client municipality in which it depends on the national government for financial livelihood. A client municipality depends on financial support from the national and provincial government and remains dependant on the upper levels of government for its financial livelihood even though it is located within a very wealthy location. Such a municipality is incapable of passing enabling municipal by-laws which can enable it to generate wealth through municipal shareholding schemes in partnership with local business in agriculture and mining. Table 1 indicates various metropolitan municipalities in South Africa and the industries that operate in their jurisdictions. 
Table 1: Metropolitan municipalities in South Africa

\begin{tabular}{|l|l|l|}
\hline Metropolitan Municipalities & Province & Economic Activity \\
\hline Municipality & Eastern Cape & $\begin{array}{l}\text { Ocean economy, Automobile, } \\
\text { Agriculture, Financial Services }\end{array}$ \\
\hline City of Cape Town & Western Cape & $\begin{array}{l}\text { Ocean economy, Automobile, } \\
\text { Agriculture, Financial Services }\end{array}$ \\
\hline City of Ekurhuleni & Gauteng & $\begin{array}{l}\text { Mining, Transport, Automobile Financial } \\
\text { Services }\end{array}$ \\
\hline City of Johannesburg & Gauteng & $\begin{array}{l}\text { Mining, Transport, Automobile Financial } \\
\text { Services }\end{array}$ \\
\hline City of Tshwane & Gauteng & $\begin{array}{l}\text { Mining, Transport, Automobile Financial } \\
\text { Services }\end{array}$ \\
\hline eThekwini & KwaZulu/Natal & $\begin{array}{l}\text { Ocean economy, Automobile, } \\
\text { Agriculture, Forestry, Financial Services }\end{array}$ \\
\hline Mangaung & Free State & Mining, Agriculture \\
\hline Nelson Mandela Bay & Eastern Cape & $\begin{array}{l}\text { Ocean economy, Automobile, } \\
\text { Agriculture, Forestry }\end{array}$ \\
\hline
\end{tabular}

Source: authors' summary

These municipalities have a huge potential of being producers of wealth than consumers of government financial support. They can buy shares in all economic sectors within their jurisdiction. This means they can improve their finances and revenue. It has been suggested that to overcome the shortcomings of fiscal decentralisation it is critical to effectively involve citizens. There are certain requirements that should be met to enhance citizen participation in fiscal decentralisation. These include political commitment and leadership from ruling parties. The increased political mobilization of various interest groups like trade unions, civic organisation, and political parties is very vital in this process. Transparent participation in decision making and creating an enabling environment for free civic participation is seen as one of the pillars that can support and enable the process to be effective and efficient. Adequate finances are essential for efficient and effective service delivery. Shortage of finance mostly culminates in poor service delivery at the local level. Quality managerial and technical expertise is important for a well-informed functioning of local government (Robinson, 2004).

Given the preceding, it is noteworthy that for effective fiscal decentralisation at the local sphere to occur, the principal participants must include the citizens in those localities. In the first place, the locals are aware of their daily developmental priorities, their service delivery needs and their socio-economic, political and 
environmental challenges, even on a long-term basis. In South Africa, the concept of IDPs emanates from the desire to be inclusive in the financial planning stages of service delivery at local levels. Technical and managerial capacity is critical for the success of fiscal decentralisation initiatives. This is the greatest challenge that contemporary South African municipalities face and many other developing countries of the South. The solution to the problems of lack of sufficient local revenues in the post-colonial, post-apartheid, and post-recession world is the adoption of the principles of New Local Government as outlined in Table 2. The idea of ProMUs implies that municipalities must produce wealth by shareholding schemes in businesses in the economic sectors around them. Producer municipalities produce wealth, rather than rely on the national government.

Most metropolitan municipalities are located in mineral-rich areas and agriculturally rich zones, which signifies the importance of their engaging in some shareholding schemes to boost revenue. Perhaps the problem lies with the management of such programmes since political interference is a problem in South African municipalities. The idea of ProMUs is a unique one and critical in the reformation of local government in South Africa. Municipalities must purchase some shares in big agricultural industries and the mining sectors within their boundaries and be able to generate more finances for themselves. They can produce and reproduce wealth by effectively using profits they obtain from municipal shares in companies which operate within their boundaries. This is one avenue which can capacitate these municipalities to be financially autonomous. 
Table 2: Twenty-two principles of the new local government

\begin{tabular}{|l|}
\hline The shift from local government services delivery to local services management. \\
\hline Efficient and effective local service management. \\
\hline Local services liberalization and deregulation. \\
\hline Local economic and natural resources empowerment and economical utilization. \\
\hline Externalization and less internalization of Local Monitoring and Evaluation (LM\&E). \\
\hline Modernization of traditional local leadership and Institutions. \\
\hline Engendering local service management competition and competitiveness. \\
\hline Greater fiscal discipline. (Less dependency on the other tiers of government) \\
\hline Inclusive local municipal services marketization and privatization. \\
\hline Greater market-clientelism than King-Subject relationship. \\
\hline Greater local-global alignment of service management systems. \\
\hline Adoption of global Transparency and Accountability Improvement Systems \\
\hline Embracing the Fourth Industrial revolution as local producers not simply client-local governments. \\
\hline Free and fair democratic local elections (with compulsory UN observation). \\
\hline Complete decolonization of local service management structures and institutions. \\
\hline Complete decolonization of local financial business and economic institutions. \\
\hline Complete decolonization of local government studies curriculum. \\
\hline Greater local cultural and social autonomy (with complete cultural decolonisation). \\
\hline Accelerated and Improved local government share-ownership(AILGSO) in all local businesses. \\
\hline New Local Government Entrepreneurship. \\
\hline New Greater Fiscal autonomy and less dependency on the national or central government. \\
\hline Promotion of greater de-politicization of local service management and local human capital \\
\hline
\end{tabular}

Source: SAAPS (2012)

In South Africa, most municipalities are located in mineral-rich areas, but the minerals are extracted and sold abroad by multi-national corporations, and the profits are repatriated abroad. The locals are left with nothing but huge mining dumps and dust-related calamities. The Johannesburg Metro Municipality and Sol Plaatje Municipality in Kimberley are good examples. The principles postulated by the New Local Government philosophy can help improve local revenues when implemented properly, especially the MSHSs. The New Local Government principles clearly demarcate what should be done in South Africa and in most parts of the world, to make the old local government work. After independence in 1994, South Africa has not totally dismantled apartheid or colonial structures of local municipal administration. Colonial and apartheid administrative architecture has been left intact, and even though it should now serve democracy with a vast and diverse population, it still has not sufficiently adapted to change. 
To successfully move into the new democracy, the local sphere of government in South Africa must adopt the above 22 principles. The philosophy is not only applicable to South Africa but the rest of the developing and developed world, especially after the 2008 economic recession. Municipalities must be able to be financially autonomous if the above principles are applied rigorously and accurately.

\section{CONCLUSION}

This article examined the forms of fiscal decentralization, merits, and demerits of fiscal decentralisation, revenues, and the principles of the New Local Government philosophy of local government reform. This article also examined fiscal sustainability and the challenges of fiscal decentralization. Fiscal decentralisation facilitates local economic development (LED) initiatives, if it is well-managed and viewed as a purely fiscal administrative process rather than a political one. In most African countries corruption from local political officials and politically appointed managers, leads to the failure of fiscal decentralisation, because to them, fiscal decentralisation means losing the centralist fiscal control they have had in postcolonial or post-apartheid governments they have controlled since independence. Fiscal decentralisation is imperative for purposes of enhancing efficiency, effectiveness, productivity, and competitiveness in service delivery at the subnational level.

However, political interference in the allocation of financial resources and weak revenue-extracting bases are the biggest challenges of most local governments. Most African countries have a lack of political will to effectively and efficiently implement fiscal decentralisation reforms, although their macro-economic policies may require such category of economic policy alignment. Central political actors are very threatened by fiscal decentralisation; thus, the lack of political will to competitively influence its practical implementation. The global financial crisis has weakened the national state fiscal leverage, thus flagging its financial muscles to propel fiscal decentralization at the local government level. The idea of producer municipalities and municipal shareholding schemes may change the face of local government revenues if properly implemented. Systemic corruption and nepotism pose an acute threat to any form of good governance within the post-independence Africa. The New Local Government principles have a great potential to reform municipal fiscal management and local government. 


\section{References}

Agrawal, A. and Ribot, J. (1999). Accountability in Decentralization: A Framework with SouthAsian and West African Environmental Cases. The Journal of Developing Areas, 33, pp. 473-502.

Alfano, M. (2009). Centralization and Decentralization of Public Policy in a Complex Framework. Eurasia Journal of Business and Economics, 2 (3), pp. 15-34.

Bardham, P. (2002). Decentralization of Governance and Development, Journal of Economic Perspectives, 16(4), pp. 185-205.

Elhiraika, A.B. (2006). Fiscal Decentralization and Public Service Delivery in South Africa. UNECA, Lusaka, Zambia.

Kauzya, J. (2007). Political decentralization in Africa: Experiences of Uganda, Rwanda, and South Africa, New York: United Nations.

McIntish, A. (1992) Decentralisation in South Africa, Regional Power and Local Government Local Government Policy Project, UWC.

Owusu, G. (2008). The role of small towns in regional development and poverty reduction in Ghana. International Journal of Urban \& Regional Research, 32 (2), pp. 53-72.

Pearce, G. and Mawson, J. (2003). Delivering devolved approaches to local governance. Policy \& Politics, 31 (1), pp. 51-67.

Peters, B.G. (1996). The future of governing: Four emerging models. University of Kansas Press. Kansas.

Pillay, S. (2008). A cultural ecology of new public management. International Review of Administrative Sciences, 74 (3), pp. 373-394.

Pillay, U Tomlinson, R. \& Du Toit, J. (2006). Democracy and Delivery: Urban policy in South Africa. HSRC. Cape Town.

Ribot, J.C. (2002). African decentralization: Local actors, powers and accountability, United Nation Research Institute for Social Development, UNRISD, USA.

Robinson, R., and Stiedel, D. (2001). Decentralisation of road administration; Case studies in Africa and SIA. Public Administration and Development, 21, pp. 53-64.

SAAPS, (2012). Political Decentralisation in South Africa: Assessing the Viability of the Three Sphere System of Government, Paper presented at SAAPS Conference, NMMU, Port Elizabeth, South Africa.

Schneider, H. (1999). Participatory governance in poverty reduction. Journal of International Development, 11 (4), pp. 521-534. 
Schoeman, N.J. (2005). Rethinking fiscal decentralization in South Africa. Unisa, South Africa.

Shah, A. (1994) The Reform of intergovernmental fiscal relations in developing and emerging market economies; Policy and Research Series No .23; World Bank.

Smith, B.C. (1985). Decentralization: The territorial dimension of the state, London: George Allenand Unwin, Boston, Mass.

Smith, D.M. (1992). The Apartheid City and Beyond; Urbanization and Social Change in South Africa, London: Routledge.

Smoke, P. (2001). Fiscal Decentralization in Developing Countries: A Review of Current Concepts and Practice. Geneva: United Nations Research Institute for Social Development.

Teehankee, J.C. (2003). New Public Management: Lean State, Lean Government, Seminar Feb9-16, Manilla.

UN, 2006. International guidelines on decentralization and the strengthening of local authorities, UN-Habitat. New York.

USAID, 2009; Democratic Decentralisation Programming Handbook. United States Agency.Van Donk, M.; Swilling, M.; Pieterse, E. \& Parnell, S. (2008). Consolidating Developmental Local Government: Lessons from the South African experience. UCT. Press. Cape Town.

Wunsch, J. and Oluwu D. (1990). The Failure of Centralised State; Institutions and Self Governance in Africa, Westview Press. California, USA.

Wunsch, J. and Olowu D. (1996). Regime transformation from below: Decentralization, Local and

Democratic Reform in Nigeria, Studies in Comparative International Development. 31 (4), pp. 66-82. 